\title{
Foreign Direct Investment in the United States During the Financial Crisis
}

\author{
Silvio Contessi, Economist \\ Li Li, Research Analyst
}

$\mathrm{E}$ mpirical studies show that multinational firms continue to invest in their host country-and even increase investment-after a financial crisis. This flow of capital from multinational firms into the host country is called foreign direct investment (FDI). Little is known about FDI behavior in the United States during the recent financial crisis, but this essay uses recently released data for a preliminary investigation.

\section{FDI flows from overseas parent companies contracted, but intracompany debt and reinvested earnings were affected much more than equity FDI.}

The financial account in the Bureau of Economic Analysis (BEA) Balance of Payments records various types of international financial flows, including FDI by multinational firms, portfolio flows, sovereign debt flows, and bank lending. Investment by foreign parent corporations in their U.S. affiliates is called inward FDI; investment by U.S. parent corporations in their foreign affiliates is called outward FDI. This measurement of cross-border financing includes not only equity investment (to establish new firms, acquire existing firms, or increase equity of the affiliates) and intracompany debt but also reinvested earnings in the affiliate's host country. Inward FDI among all nonfinancial industries was about $\$ 207$ billion or 12.7 percent of U.S. nonresidential fixed investment in 2007; this represented about 10.7 percent of all capital flows in the United States in the same year.

These cross-border flows do not necessarily map one to one with affiliates'

\section{U.S. Inward FDI: Manufacturing Industries}

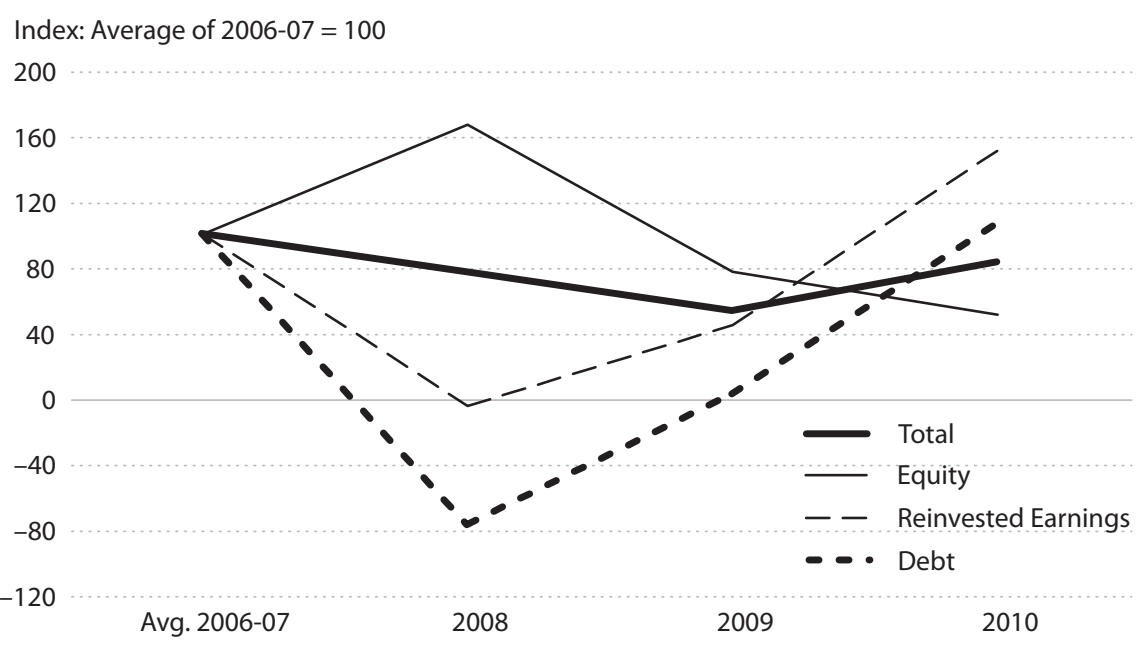

SOURCE: Bureau of Economic Analysis. expenditures on capital, structures, and research and development because the expenditures can be partially financed by raising funds in the host economy. In this case, only a share of the expenditures for investment is captured by the balance of payments notion of FDI. Investment by U.S. affiliates of multinational firms in all nonfinancial industries was almost 8 percent of gross fixed capital formation in $2007 .{ }^{1}$

In this essay, we use these two measures of FDI in U.S. affiliates of foreign multinational corporations-the balance of payments notion of FDI and the capital expenditure notion of FDI-during the recent financial crisis to study the changes to FDI during the crisis. We focus on inward FDI in manufacturing industries.

The chart plots the evolution of inward FDI flows in manufacturing industries between 2006 and 2007 (averaged) and the most recent year available (2010) as a total and by three major components. Although all the components contracted, following a V-shaped pattern common to many economic 


\section{Percentage Change in Investment between 2008 and 2009 by Industry}

\begin{tabular}{|c|c|c|c|c|c|}
\hline \multirow[b]{2}{*}{ Industry classification } & \multirow[b]{2}{*}{ Manufacturing } & \multicolumn{2}{|c|}{ By industry output } & \multicolumn{2}{|c|}{$\begin{array}{l}\text { By measure of dependence } \\
\text { on external finance }\end{array}$} \\
\hline & & Durables & Nondurables & Dependent & Less dependent \\
\hline U.S. economy & -24 & -35 & -1 & -27 & -29 \\
\hline No. of industries & - & 7 & 2 & 3 & 2 \\
\hline
\end{tabular}

SOURCE: Bureau of Economic Analysis.

series (for example, exports and imports), intracompany debt and reinvested earnings dropped sooner (in 2008) and more sharply than the equity component. A possible explanation for these differences is that the cost of financing in the source economy increased at the peak of the crisis, while equity investment may have been planned and financed before the crisis and was simply carried out as planned once the crisis hit (Contessi and De Pace, 2011). Compared with the 2001 recession, these series show similar patterns but more marked contractions, particularly in intracompany debt.

The BEA also provides data on the expenditures on property, plant, and equipment by U.S. affiliates of foreign multinationals. Was the drop in the capital flows measure of FDI reflected in changes in expenditures by affiliates? The data show that it was. Similar to the capital flows measure, expenditures by U.S. affiliates in manufacturing industries contracted markedly during the $2008-09$ recession ( -26 percent), which was about the same as the change in investment in the U.S. economy overall ( -24 percent).

To analyze what caused such a contraction we regrouped industry-level data according to two classifications: (i) durable goods versus nondurable goods industries and (ii) industries more dependent versus those less dependent on external finance. ${ }^{2}$ These classifications also capture two important factors that affected investment decisions during the Great Recession: the demand for durable goods and the role of finance.

The data in the table show changes in investment for selected industry classifications and confirm previous findings that between 2008 and 2009 sectors producing durable goods generally suffered much more than those producing nondurable goods. As the future outlook of the economy appeared more uncertain, consumers cut back on their consumption of durable goods (e.g., cars and computers), which in turn affected investment. The table also suggests a puzzle: Unlike the U.S. economy at large, affiliates' expenditures do not show a sharp distinction between durables and non- durables industries, a fact perhaps related to the limited number of industries we could match using public data.

Another puzzling aspect is the role of finance. Investments by foreign-owned affiliates in industries with higher external finance dependence contracted relatively less than domestic investment overall and less than affiliates in industries characterized by less external finance dependence. A possible explanation is that affiliates in industries that generally depend more on external finance could rely more on their multinational network of internal capital markets for financing than could other firms facing external finance difficulties. There also may be something specific to these industries that our analysis or data cannot capture.

In summary, our analysis shows three facts: (i) FDI flows from overseas parent companies contracted, but intracompany debt and reinvested earnings were affected much more than equity FDI. (ii) Expenditures of affiliates and in the U.S. economy overall dropped by similar percentages. And (iii) affiliates in industries that are more dependent on external finance may have relied more on internal capital markets, which helped them to cushion the reduced investment.

\footnotetext{
${ }^{1}$ This ratio should be taken with some caution as the numerator and denominator include different types of investment.

2 We use the conventional Rajan and Zingales (1998) measure of a firm's requirement for outside capital (i.e., the fraction of total capital expenditures not financed by internal cash flows from operations). It should be noted that the industrylevel data are collected at the firm level, whereas data for investment in private fixed assets are the product of statistical estimates derived from data at the establishment level. We used the manufacturing industries for which industry-level data were reported for all years of interest; 2008 is set as the base year of this analysis.
}

Contessi, Silvio and De Pace, Pierangelo. "The (Non-)Resiliency of Foreign Direct Investment in the United States during the 2007-2009 Financial Crisis." Working Paper No. 2011-037B, Federal Reserve Bank of St. Louis, October 2011, revised January 2012 (forthcoming in Pacific Economic Review).

Rajan, Raghuram G. and Zingales, Luigi. "Financial Dependence and Growth." American Economic Review, June 1998, 88(3), pp. 559-86. 